\title{
Hanover Street: An experiment to train women in welding and carpentry
}

Peggy Antrobus

Barbara Rogers

Follow this and additional works at: https://knowledgecommons.popcouncil.org/departments_sbsr-pgy

Part of the Economic Policy Commons, Family, Life Course, and Society Commons, Gender and Sexuality Commons, International Public Health Commons, and the Regional Economics Commons How does access to this work benefit you? Let us know!

\section{Recommended Citation}

Antrobus, Peggy and Barbara Rogers. 1980. "Hanover Street: An experiment to train women in welding and carpentry," SEEDS no. 2. New York: Population Council. 
SEEDS is a new pamphlet series developed to meet requests from all over the world for information about innovative and practical program ideas developed by and for low income women. The pamphlets are designed as a means to share information and spark new projects based on the positive experiences of women who are working to help themselves and other women improve their economic status. The projects described in this and future issues of SEEDS have been selected because they provide women with a cash income, involve women in decision-making as well as earning, are based on sound economic criteria, and are working successfully to overcome obstacles commonly encountered. The reports are not meant to be prescriptive, since every development effort will face somewhat different problems and resources. Rather, they have been written to describe the history of an idea and its implementation in the hope that the lessons learned can be useful in a variety of settings. They are also being written to bring to the attention of those in decision-making positions the fact that incomegenerating projects for and by women are viable and have important roles to play in development.

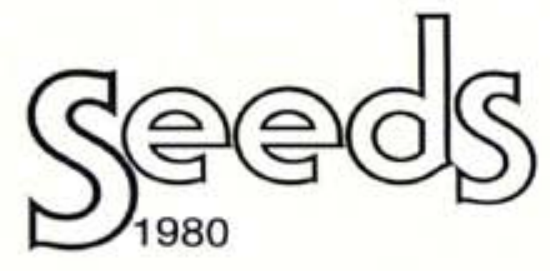




\title{
Hanover Street: An Experiment To Train Women in Welding and Carpentry
}

\author{
Story by Peggy Antrobus, \\ with Barbara Rogers
}

\section{Introduction}

The Hanover Street Project, formally known as the United Women's Woodworking and Welding Project, is an experiment in training women for jobs usually held only by men. Begun in 1976, this was the first such program of the Jamaica Women's Bureau, established by the Government during International Women's Year to insure that women participate fully in Jamaica's development. Though the project is still developing, it has demonstrated that low-income women can learn non-traditional skills and can work together to improve their lives. Through trial and error, the project is providing the Women's Bureau with a wealth of information about teaching technical skills, working with other government agencies, and establishing self-sufficient cooperative structures. The knowledge gained from Hanover Street is being applied to a number of new projects organized by the Bureau in urban and rural areas. The lessons from this experience extend beyond Jamaica and, hopefully, will be useful to people in other countries who are addressing similar problems. 


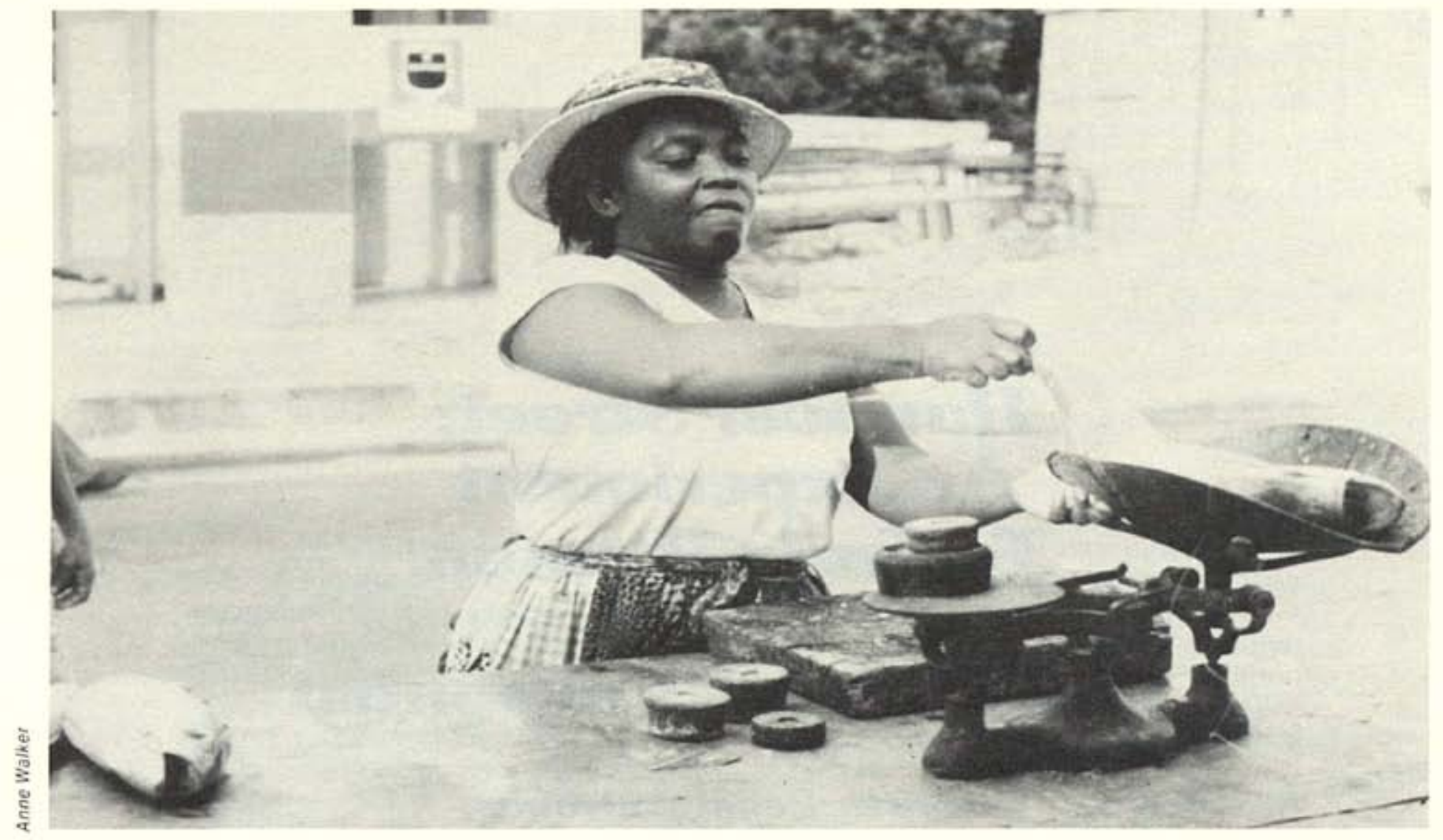

Soon after the Women's Bureau was established in 1975, it held 13 workshops throughout the country to ask the women of Jamaica about their needs and aspirations. In every case, the women's overriding concern was employment and skills training to earn income. The need was clear, but what could a small government agency with limited staff and budget do?

Jamaica, like many developing countries, has a severe unemployment problem. Its 2.1 million people occupy a 4,400 square mile island in the Caribbean that, although independent since 1962, is still trying to deal with a legacy of colonial exploitation that has left it with a narrow economic base dependent on the export of sugar and bananas, the mining of bauxite, and tourism. Unemployment is $12 \%$ for the country's men and $32 \%$ for its women. Women's unemployment is particularly important in Jamaica since at least one-third of all the households are headed by women at any one time and even more households will experience some period during which the woman is the only wage earner. The women who do manage to find employment usually have jobs in low paying, marginal and unskilled occupations.

As in most parts of the world, skill training for women in Jamaica has been limited to activities termed "home econo- mics" or "crafts." Such training may lead to employment as a domestic worker or to part-time work in the tourist trade, but it cannot bring women into the mainstream of economic life. The Women's Bureau staff therefore determined to develop a skills training program that would provide lowincome women with a better means of earning a living. To do this they had to find out which skills would be marketable within the women's own communities since formal employment, especially jobs in industry, are very scarce in Jamaica.

In planning their training program, the Bureau had several objectives:

(1) to demonstrate that a group of lowincome, low-skilled women can, with assistance, become economically self-sufficient, and integrated into the economic mainstream;

(2) to design a model training program for others to use and adapt based on sound economic and social criteria that would assist women in their economic, domestic and mothering roles;

(3) to show how existing government programs could work together for women.

To begin, the Bureau staff sought the advice of the Small Industries Division of the Jamaica Industrial Development Cor- 
poration. The Division estimated that there would be increasing demand for furniture and equipment for daycare centers given the Government's interest in child care. They also thought there would be some demand for such items from private homes and schools. The basic skills required were carpentry and welding.

66

\section{In my community people have a better feeling about me. They know I made my own bed.}

- Delta McFarlane, woodworker

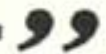

As a small organization with limited funds, the Bureau could not possibly put together a training program on its own. Moreover, since one of the objectives of the project was to ensure that more women benefited from all Government programs especially those in which their participation had been low - the training program was developed in collaboration with several Government agencies. The Bureau first approached the Vocational Training Division of the Ministry of Youth which operates several Vocational Training Centers. Although open to women and men on an equal basis, only $12 \%$ of the places in their programs were occupied by women in 1974, and most of these women were taking classes in home economics, dressmaking, waitressing or secretarial skills. The Vocational Training Division agreed to provide training in welding and carpentry to women in collaboration with the Women's Bureau which would design and administer the program.

Skills in carpentry and welding, however, would not be sufficient. Since unemployment generally is so high, most of the women probably would have to become self-employed. As such they would face problems obtaining equipment and raw materials, maintaining a viable level of production, and marketing their products. Thus it was decided that the women also would be trained in management and accounting skills that would enable them to form a production and marketing cooperative. In addition, the Bureau decided the training program should recognize women's multiple roles by offering family life education on such topics as child care, health, nutri- tion, family planning and self-awareness.

"In fact, the women themselves selected the topics for this course and consciousness. raising discussions quickly became an integral part of the training program."

\section{Developing the Project}

First the Bureau had to decide which women could be included in the program. Their modest resources wouldn't allow them to reach all poor women. The next best option was to develop a project that would demonstrate to other agencies how they could work with the thousands of women needing a means to earn a living.

The Bureau therefore turned to two existing Government programs: the Special Employment Programme (SEP), maintained by the Jamaican Government to provide small, but regular, salaries for manual work such as street sweeping to very poor, unemployed people; and the Jamaican Movement for Adult Literacy (JAMAL). The majority of participants in SEP and JAMAL are women, many of them enrolled in both programs. These programs provide a minimal income but not self-sufficiency or opportunities for advancement.

In January, 1976, a series of meetings was held for all those enrolled in both SEP

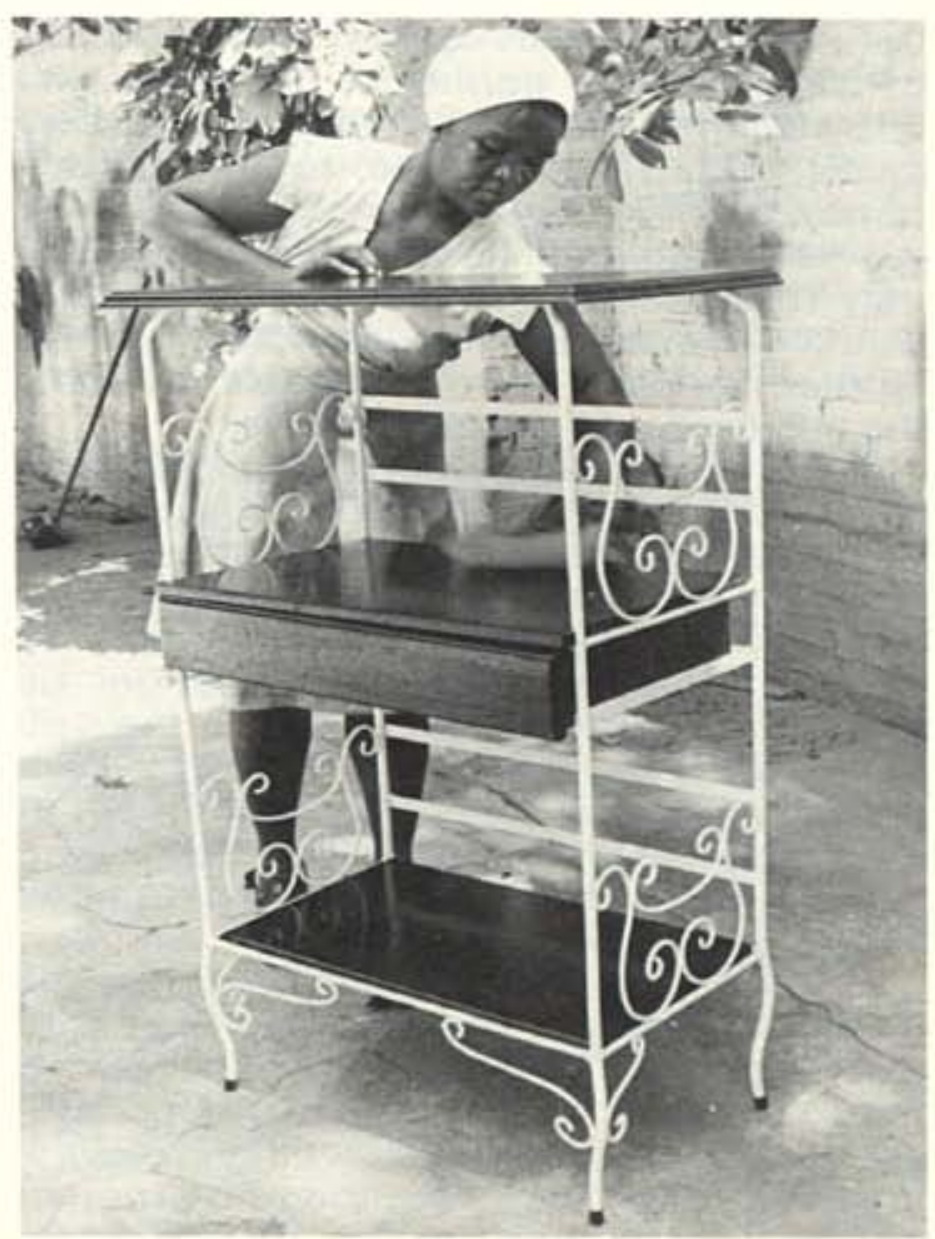



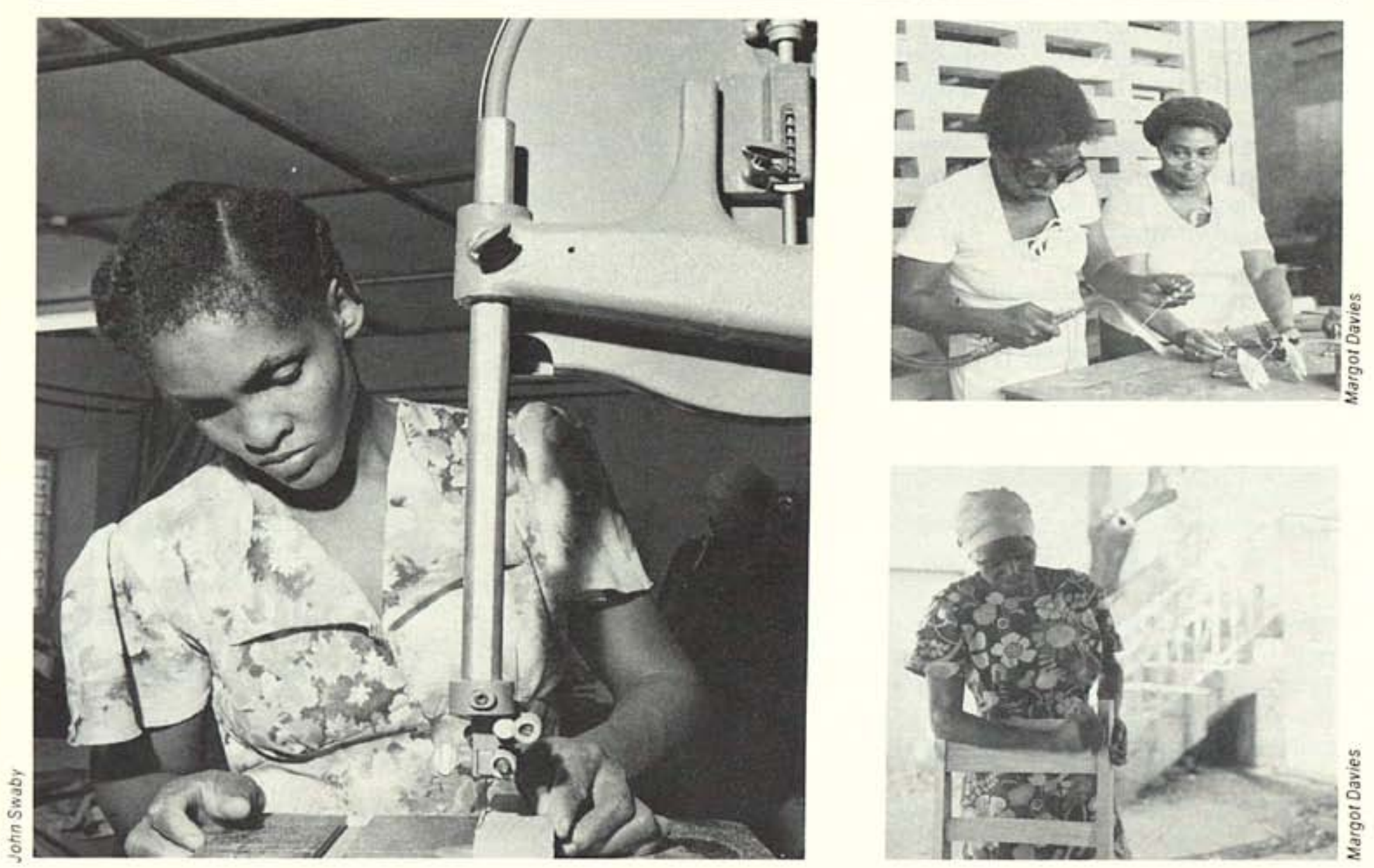

and JAMAL who 1) had reached level 4 in the JAMAL program, 2) lived within the city of Kingston (the capital of Jamaica), and 3) were interested in training in carpentry or welding. It was decided to limit participation to those who had reached level 4 in the literacy program because it was assumed they would be at a similar level of literacy, would have experience attending classes regularly, and would be better able to handle the business end of a cooperative.

At each meeting Women's Bureau representatives outlined the program and invited people to apply. They stressed the risks involved: participation meant eventually leaving SEP and beginning a different way of life; income would no longer be fixed but would be dependent on the output of the group and the demand for their products. On the other hand, members of a cooperative would be able to make their own decisions and control their own operation.

Over half of those present at the meetings applied. Follow-up meetings were then held for these applicants during February and March to give them more details on the program as well as to allow the Bureau staff to select the first group of trainees. Forty-eight of the 70 applicants were chosen. Preference was given to those in peak earning years, to those who were the only source of support for their families and to those living reasonably near the training centers. Among the forty-eight, were two men - which is two more than the number of women in any previous welding or carpentry training course!

\section{Training}

The training phase began on March 8 , 1976 - International Women's Day. Trainees were invited to choose either carpentry or welding. Classes were conducted at three existing training centers run by the Vocational Training Division. All three sites offered welding and two, carpentry. The vocational classes were taught 24 hours each week by staff recruited and trained by the Division, but paid by the SEP program. For six hours each week the entire group from the three centers met together for a course in family life education given by the Ministry of Health and for sessions on cooperative development and consciousness raising given by the Women's Bureau staff.

The agencies participating in the training program and their responsibilities are as follows: 
Government Agencies

Women's Bureau

Vocational Training Division

Bureau of Health Education, Ministry of Health

Cooperatives Division, Ministry of Agriculture

National Savings Committee SEP

JAMAL

Non-Governmental Agency

Jamaica Children's Services Society
Responsibility

Design and management of the program; organization of human relations training.

Skills training

Family life education

Training in cooperative skills

Advice on development of credit unions

Maintenance stipend

Continued interest and support

\section{Responsibility}

Sessions in child guidance and counseling
The training period was originally set at six months, but was extended to eight for several reasons. The involvement of a number of agencies over which the Bureau had no direct authority posed some difficulties. Although the Bureau had discussed the program in detail with each of the participating agencies, common problems that arose included irregular attendance by some staff members, inappropriate handling of the group, and poor communications techniques. The participants were quick to sense any lack of interest on the part of training personnel and they had the selfassurance to point this out. Many of the staff members, accustomed to traditional teaching situations, had difficulty relating to these adult students. Such problems were resolved on an individual basis by the Bureau staff, but the process took considerable time and perseverence.

There were also many instances where raw materials arrived late or where there were shortages in the shipments. These problems the Bureau found more difficult to handle since they involved snags at many levels in the bureaucracy. Again, persistence and careful coordination were necessary. Another important but unanticipated problem was lack of child care, the most frequent cause of absence among the participants. No provision for child care had been made at the training centers since it was assumed the women had made their own arrangements for their children when they joined SEP.

Toward the end of the seventh month, two weekend residential sessions were arranged so that the participants could re- ceive more intensive training in cooperative development, interpersonal relationships and problem solving. These sessions were held at the Social Welfare Training Centre located at the Extra-Mural Department of the University of the West Indies. It was the first time that any of the women had been involved in a residential training program and for many it represented their first time away from their families in this kind of setting. The training emphasized participation. The group was presented with particular problem situations and asked to develop solutions through cooperation, careful attention to interpersonal relationships, and special efforts to communicate effectively with each other. In this way they gained experience in decision-making and problem-solving. And they began to develop stronger self awareness. For all,

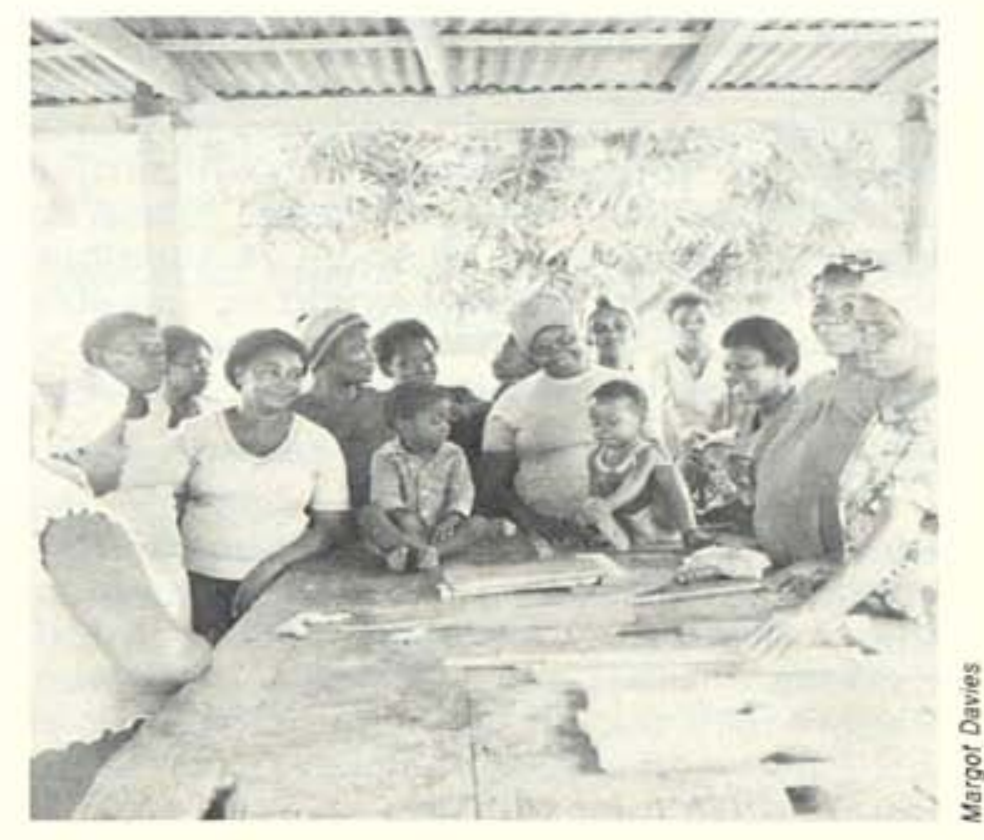


both staff and trainees, the residential sessions represented the high point of the training. It seemed to consolidate the group cohesiveness which had been building throughout the training period.

\section{Apprenticeship}

As the training period neared an end, it became clear that the newly trained welders and carpenters could not just open up shop the day training was completed. An apprenticeship period was needed to enable the women to begin production and to develop a cooperative structure. Continued support and assistance by the Bureau, SEP and JAMAL during this period was crucial.

The group could not, of course, immediately generate enough income to cover its costs and the financial needs of its members and the Bureau did not have sufficient financial resources to support the project during this critical stage. Fortunately, SEP agreed to continue the members' stipends throughout the start-up ceiving the SEP payments; so far the group is not economically strong enough to do this. The road from training to self-sufficiency has been a lot rougher than anticipated.

Shortly after the project commenced regular operation, the Women's Bureau expanded its activities to assist in the development of rural pilot projects. They could no longer provide the project with the fulltime services of a project officer. Everyone assumed that the group could be more or less independent after receiving the technical training and courses in cooperative management. This assumption, however, proved unrealistic. The women did not have a sound understanding of cooperative principles; the management structure was untried and not fully developed; not enough orders were generated in the first months

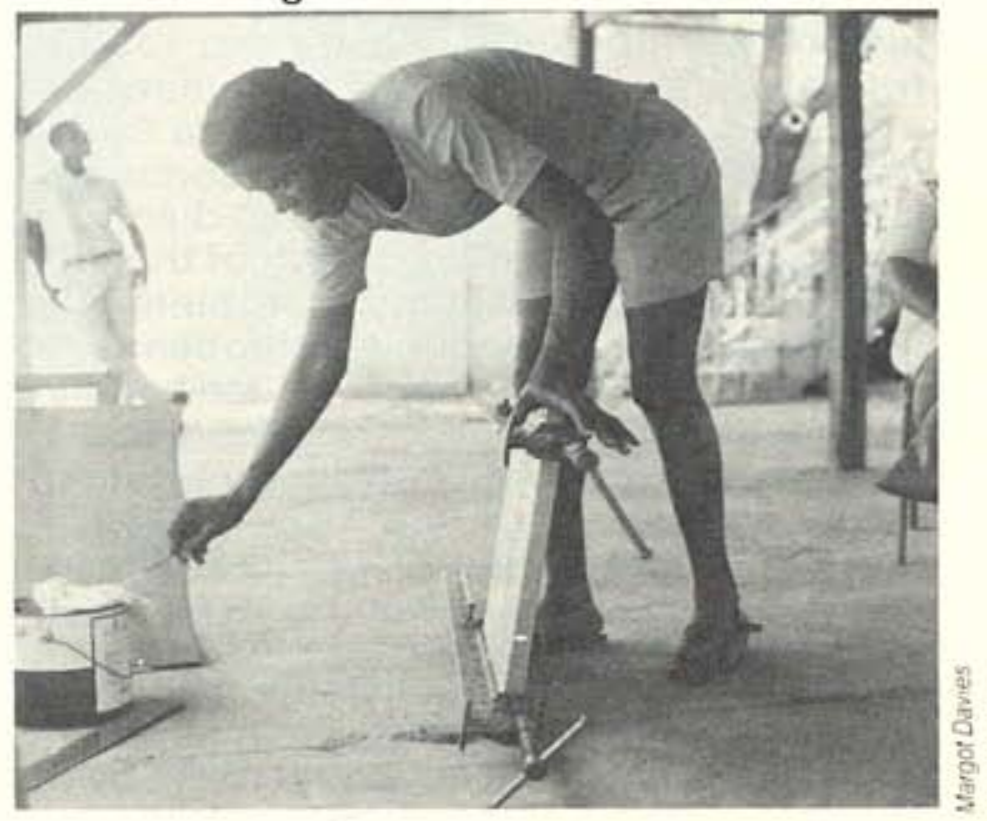

to keep up production; and no proper bookkeeping system was in place.

All of these factors led to low morale, and discipline started to deteriorate. But the Bureau and the women continued to work together to find solutions to their problems. Throughout this difficult time the Bureau staff resisted the temptation to take control of the project. Instead they encouraged the women to work together to solve their problems themselves, recognizing that they would make mistakes but that they could learn from their errors with help and encouragement from the Bureau.

One of the very serious problems encountered by the group involved the SEP payments to participants. Initially, payments were given to each member regardless of how hard the person worked or how much responsibility she/he had taken. This 


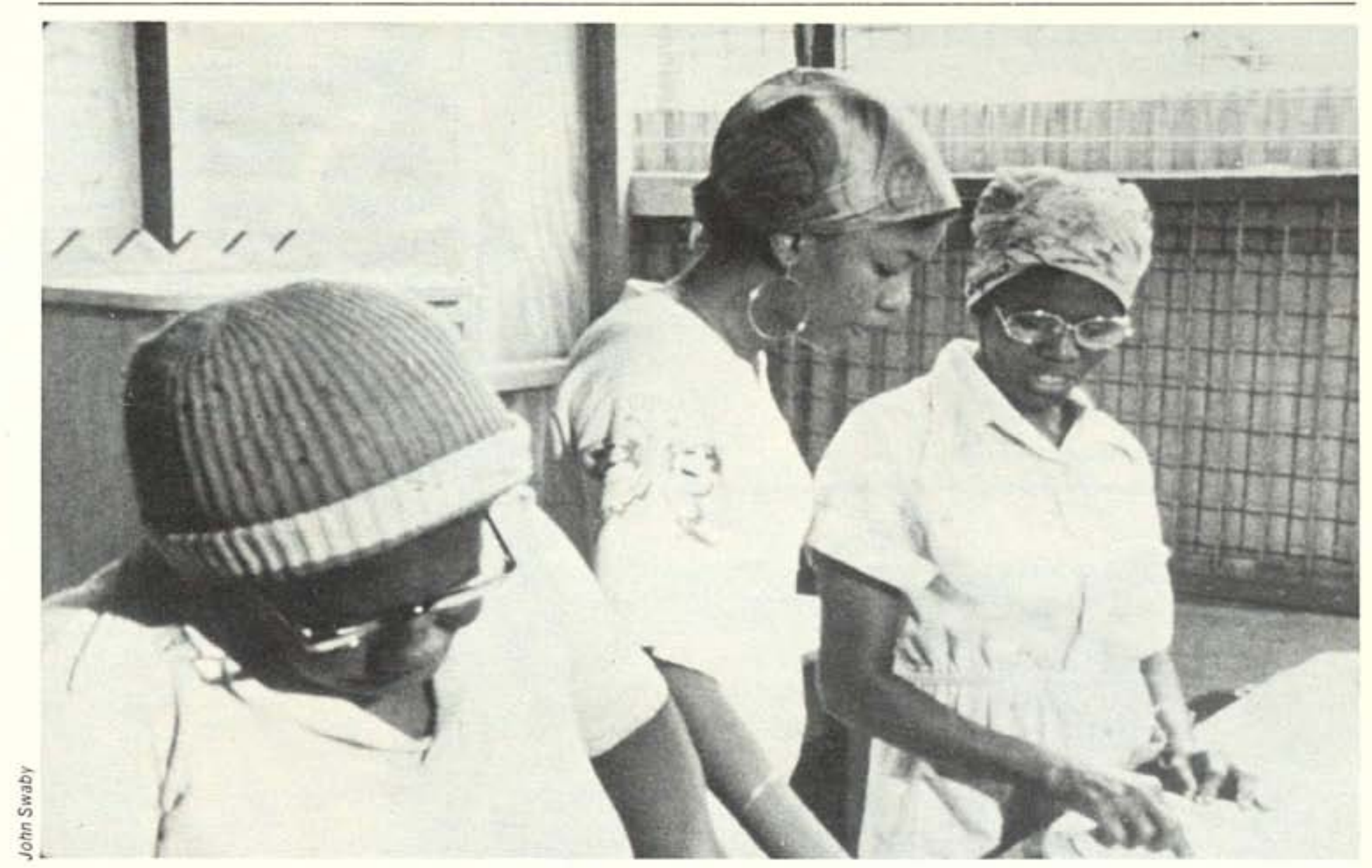

caused much dissension. The Bureau has been able to help by suggesting that SEP make one lump payment that a newly-hired project manager will distribute among the participants according to their individual productivity. This is a step in putting the project on a solid footing since it means that what a member earns will depend upon how much effort she/he puts forth.

The initial decision to manufacture day care furniture and equipment also turned out to be problematic. Demand was not nearly as high as anticipated and the project found it difficult to compete with the mass-produced goods imported from developed countries. The cost of raw materials began to increase and the furniture designs, while attractive, took considerable time to make. It thus became more and more difficult for the group to make a profit. The women decided to expand the items manufactured to include desks, chairs, coffee tables, plant stands, iron grills for windows, household fixtures, ash trays, and lamps which they thought would be in demand locally. Currently most of the orders the project receives come from Government ministries. With additional training and advice, the group hopes to expand to include private buyers. However, as the women had not received courses in marketing during the training period, they were in need of practical knowledge and advice about finding markets and generating demand for their products. Since many of these women already have some experience as petty traders, the program is now trying to build upon these practical marketing skills with assistance from CADEC, Bureau staff, and consultants.

I feel miserable because markets are very scarce, but I feel better for having a skill. If this project should close down I could go out and get a job.

- Maudlyn Russell, welder

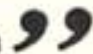

Today, of the original 48 participants, 26 women and one man remain. Some of those who dropped out were those either unwilling or unable to shoulder the burdens and risks of running a cooperative enterprise. In other cases, participants left to take higher paying jobs - testimony to the 

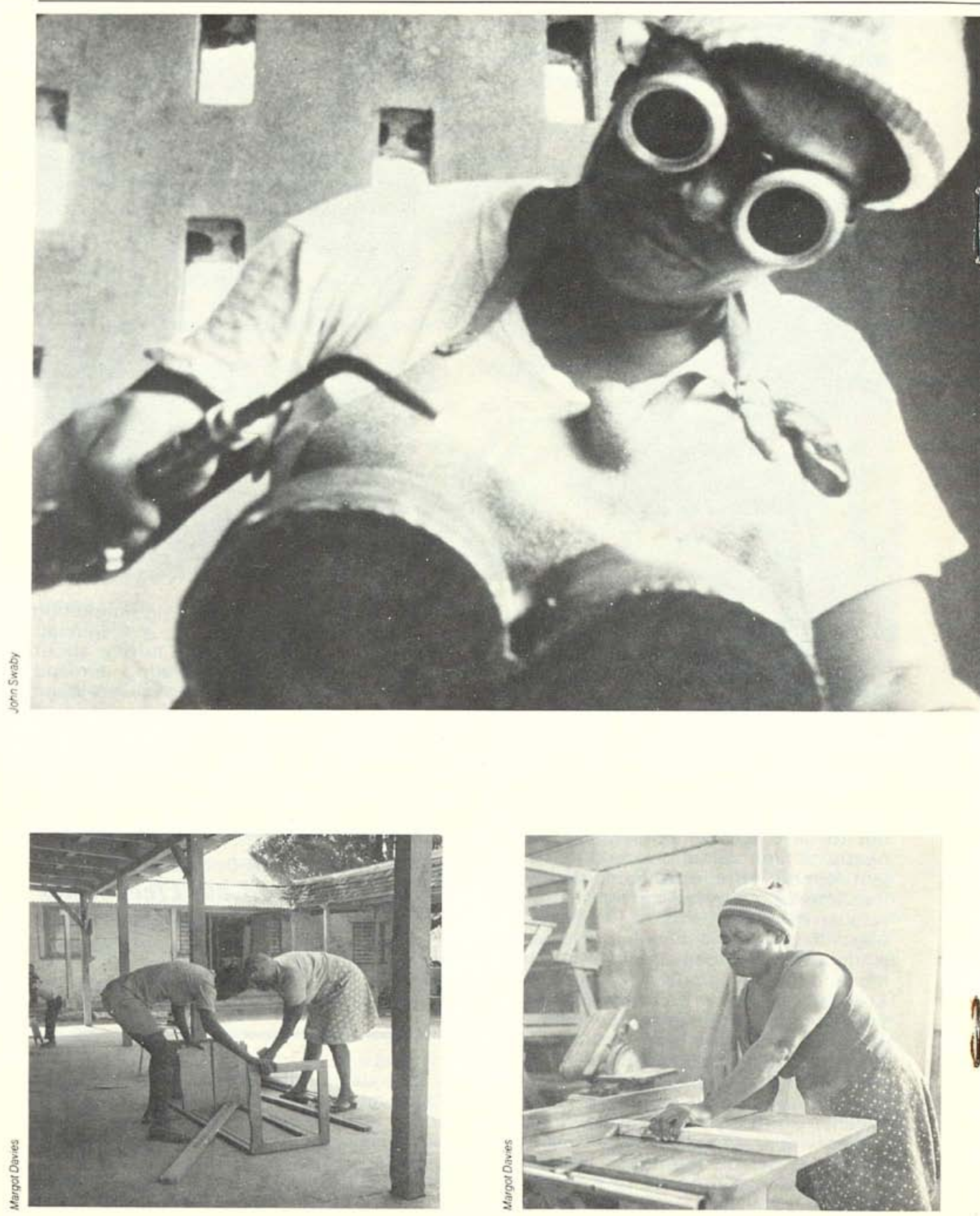


\section{6}

Ijoined the programme because I had a skill (dressmaking) but it keeps me confined. Welding seemed more challenging. I was more interested in painting but that fell through. Then with 4 children to support alone I wanted something more.

- Cynthia Anderson, welder

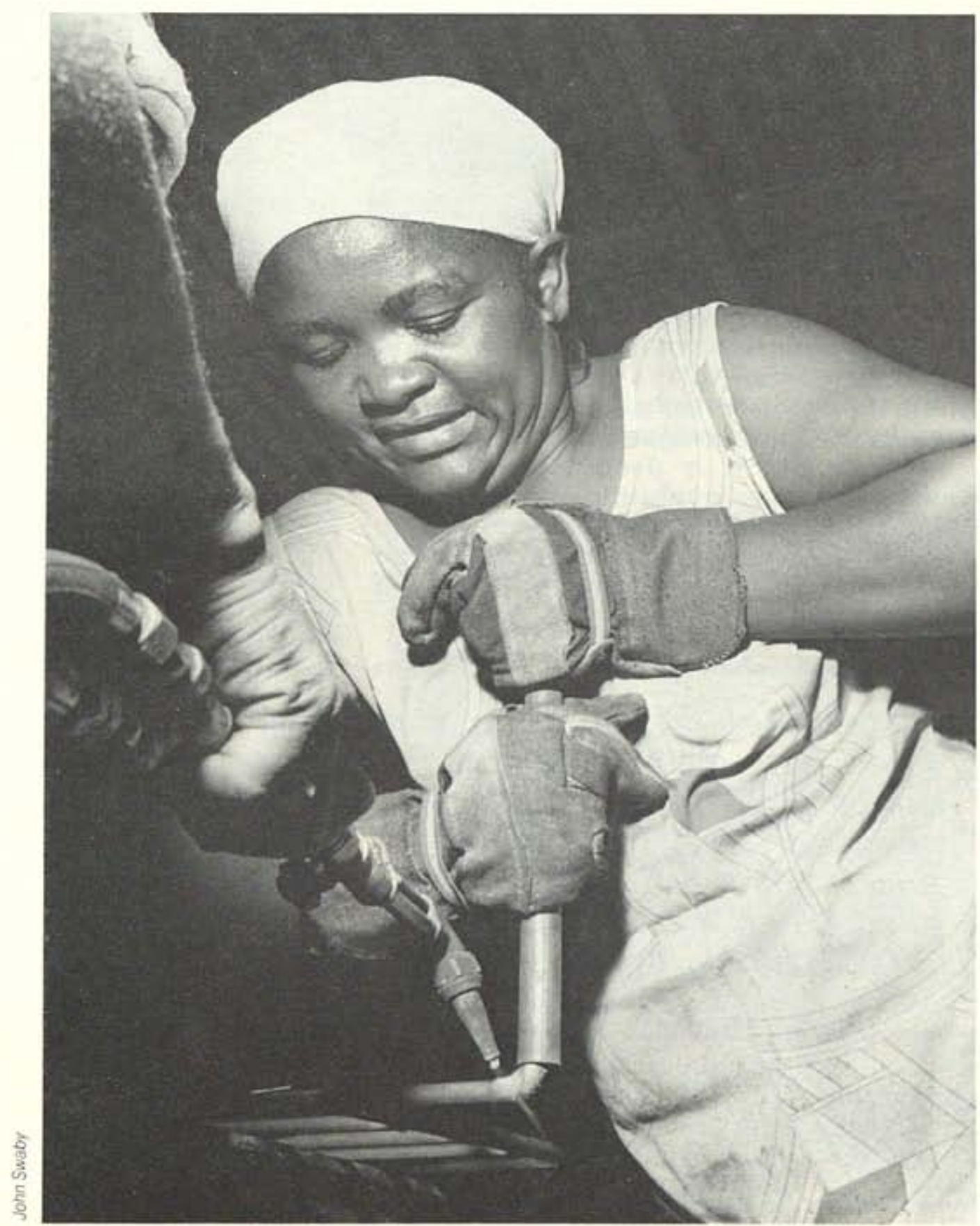




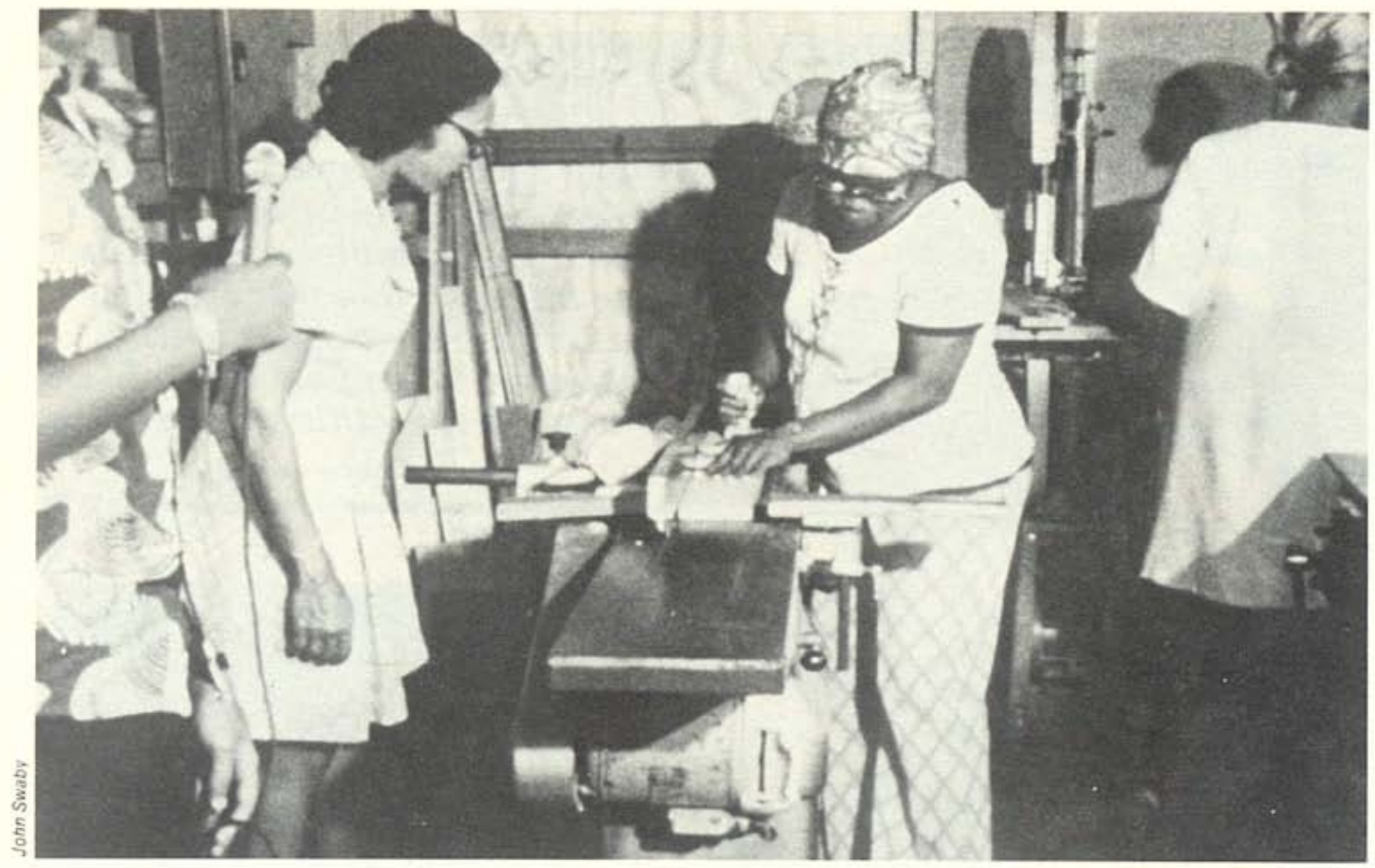

success of the training effort. The remaining group are well aware of their problems and are intent on taking the steps necessary to put their enterprise on a solid footing. Income currently averages U.S. $\$ 1,000-\$ 3,000$ per month which is used for materials, utilities and other operating costs. Rent is still subsidized by the Government, as are salaries; grants from other agencies are used to support further training efforts and to bring in outside expertise.

66

I feel better about myself because Inow have a trade. Things I would have given out to have made or fixed, I now can do myself. My family life has improved because now I know more about family living.

- Maud Lawrence, welder

\section{The Future}

The project members have restructured the group's activities so that members, rather than the Women's Bureau Project Officer, are taking a more active and primary role in decision making. To put the business side in order they are hiring a project manager for 2 years, using funds provided by CADEC. Two women from the co-op will work as accountants and will understudy the manager so they can gradually assume these duties themselves. Marketing problems are being given priority with assistance from the Small Industries Corporation and CADEC. Even as they are learning more about how to market goods effectively, they are finding outlets for their products among neighbors and friends. The Bureau has put them in touch with the Regional Child Development Centre at the University of the West Indies which designs new kinds of toys and equipment for child care centers in the Caribbean, and it is working to identify similar demands in other Government programs.

The group also has decided to establish a day care center for their own children and for the children of other women in the neighborhood. The problem for the group has not been with pregnancy or with infants. Several members who became pregnant have continued to work with strong support from the others. There are a few cribs in the workshop for small babies and mothers can feed them during their breaks. Problems begin to arise when children become mobile. 
Currently the women must rely on temporary child-minding by unemployed women in their neighborhood who frequently, and usually without warning, are unavailable for any number of reasons, or by older children who must be kept home from school. The child care facility will not only help the project members stay on the job, but will benefit the community as well. The Bureau has agreed to help arrange training for day care staff and is now convinced that any income-generating project for women must have child care built in from the start.

Other activities have been requested by the members including continuing education in design, marketing, and management, plus upgrading of technical skills. Several members plan to participate in adult education courses. Others are anxious to continue the family life education classes introduced during the original training

\section{I want the programme to succeed and if the programme succeeds then I will succeed.}

- Cynthia Anderson, welder

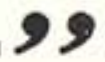

period. They have started a "partner" savings club, run exclusively by the participants, which has been useful to the women in times of crisis. The group has also established a buying club so that they can purchase foodstuffs in bulk at a considerable savings. Food purchased by the club is also used to provide one hot meal a day to the workers on the job.

The Hanover Street building will soon become the location for a new, multiagency women's program. The project occupies a site with two vacant buildings. The Women's Bureau, in cooperation with the Ministry of Local Government, is renovating one building as an office and storeroom for the project. The other building will provide day care facilities and become a neighborhood training center. Classroom space will also be available for participants in the Women's Bureau's rural projects who come to Kingston for special training.

\section{Conclusion}

The Women of the United Woodworking and Welding Project have accomplished a great deal as they move from dependence on a Government scheme to participation in their own cooperative enterprise. They have overcome many obstacles and problems along the way. Out of this experience they have developed a strong group spirit and a sense of personal independence and dignity. They have also demonstrated that training in non-traditional skills is not only possible but beneficial, and can turn marginally employable women into skilled workers. This transformation has had a profound effect on the women that goes beyond their roles as earners. It has changed their perceptions of their partners, their children and themselves and has altered their attitudes towards work, health, marriage, education and family planning. For the first time in their lives, they are experiencing a sense of autonomy and are able to exert some control over the circumstances of their lives.

The project has also generated considerable publicity and community interest. Major news coverage was given to the program as an important innovation in training and employment. As a result, the project receives visitors from all over Jamaica and from abroad. This coverage has helped to draw attention to discrimination against women and to publicize the work of the Women's Bureau. It has also attracted some potential customers and done a lot to boost the confidence of the project members.

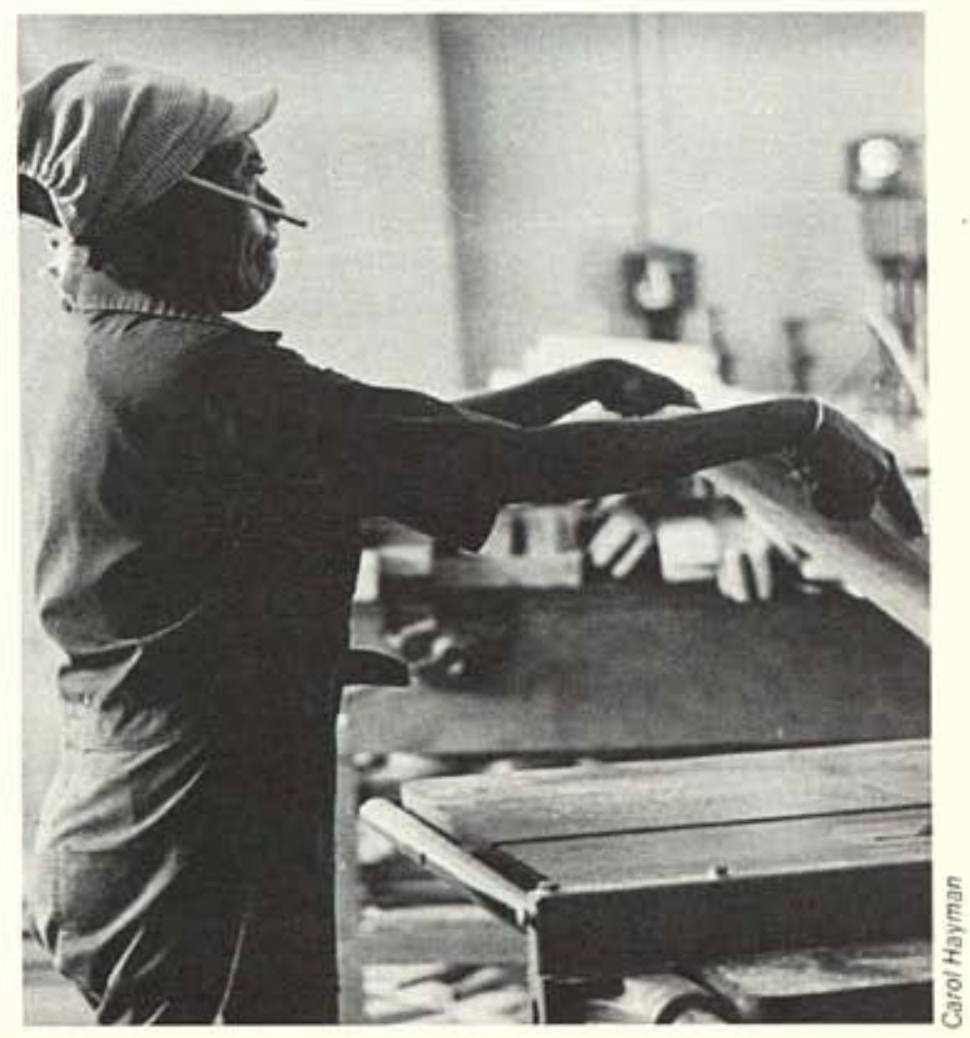




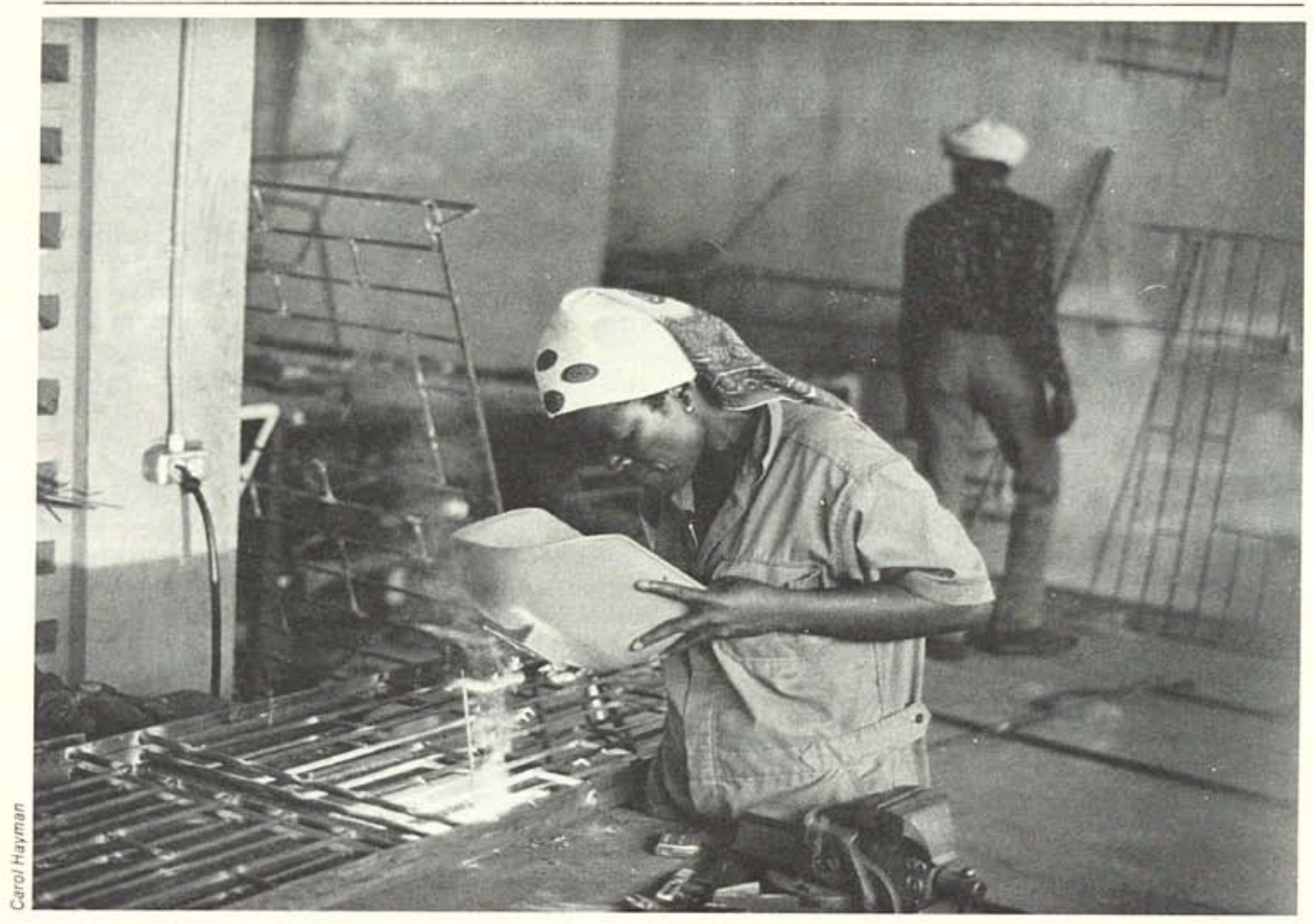

Hanover Street has enabled the Bureau to demonstrate to other Government agencies and to other women, that women need access to and can perform well in programs that traditionally have served only men. Since the Vocational Training Division began cooperating with the Women's Bureau, the percentage of women enrolled in its regular skills training programs has been going up every year! Overall, collaboration with the Bureau has provided an opportunity for a number of Government agencies to better serve the needs of women. It has also enabled the Bureau to put together a program far beyond its own limited resources and thus to reach more women.

Of course problems remain. The project still is neither independent from the Bureau nor on a strong economic footing, but the women and the Bureau staff are facing these problems together. Future efforts at launching similar projects should be able to avoid many of the pitfalls experienced by this first pioneering effort. It may be that the lessons learned by the Women's Bureau are just as important to the development process as the production and earnings generated by the project. The Bureau has learned that:

1. Before deciding on any economic project, expert advice should be sought on what to produce, how to produce it, how to maintain quality control, and how to market the products. This advice might come from a government agency, private institution or individual. It is

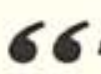

Joined programme because I wanted to be self-employed. If programme become successful I could help my children and self far better. I also liked the skill of woodwork.

- Delta McFarlane, woodworker

important for program managers and participants to ask questions and raise issues with advisors, because the more the advisors know about the situation, 


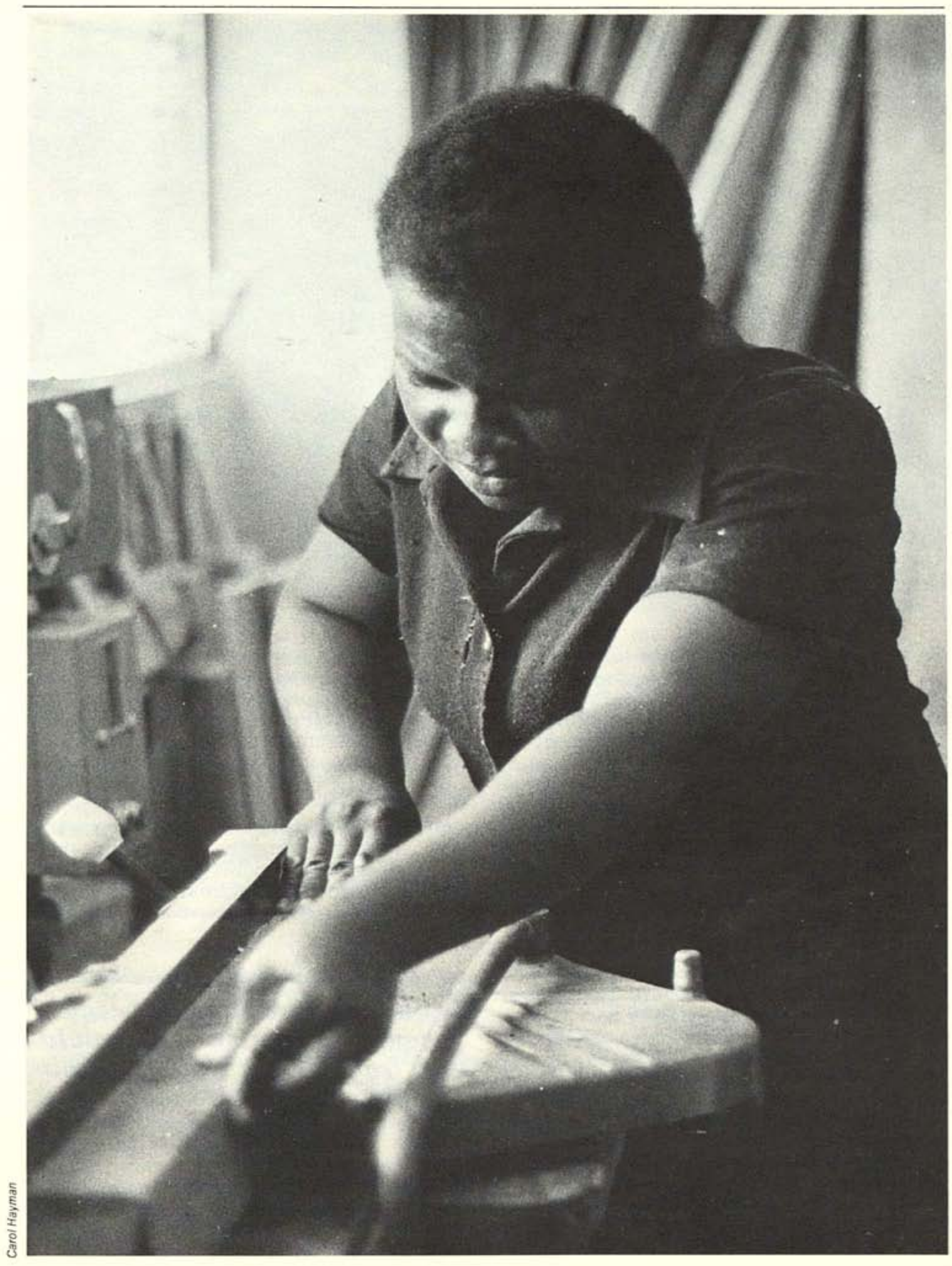




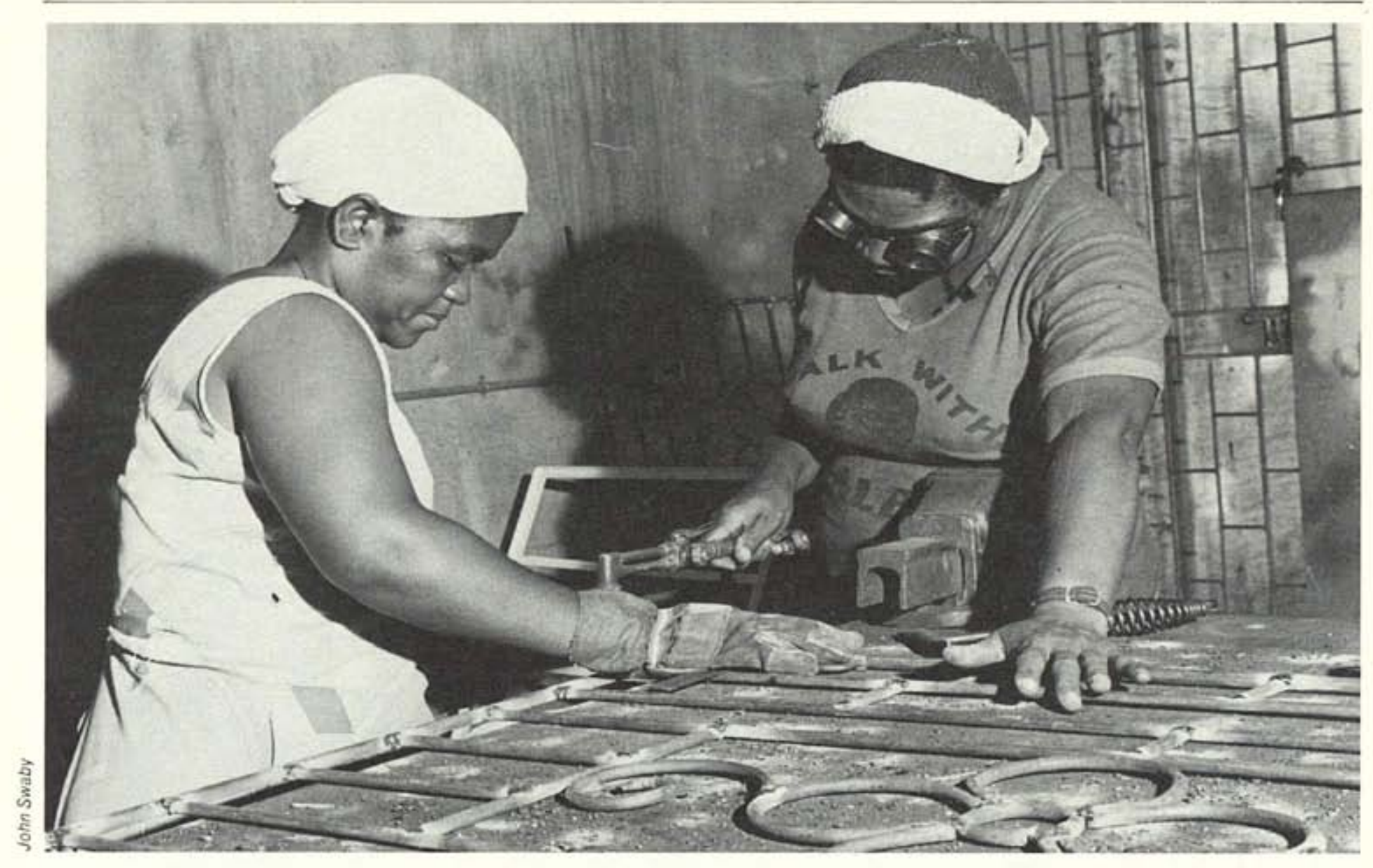

the better able they will be to give appropriate counsel.

2. Despite expert advice, economic projects can be negatively affected by changes in markets, shortages of raw materials, and other factors beyond the control of the producers. Project organizers should be particularly aware of this, warn potential participants, and take steps to minimize potential losses and setbacks. In many cases it may be necessary to plan for a considerable period of subsidy. Organizers should carefully consider such costs and their ability to meet them.

3. Pilot projects, although they directly serve only a few women, are a useful means of raising broader consciousness about women. They can create new awareness and interest on the part of key government agencies whose support is necessary to develop broader economic and social opportunities for women. They can demonstrate how existing programs can be modified and utilized for new purposes. They can serve as a training device to develop more and better programs.

4. When a government agency, like the Women's Bureau, or a private organi- zation has little money and few staff, it can - and indeed should - draw on the skills and resources of other agencies, both government and private. To do this effectively, it is necessary to:

(a) outline the program strategy carefully, yet maintain flexibility so that changes can be made as the program develops and situations change;

(b) indentify institutions and government departments that have the skills needed in marketing, product design, production systems, cooperatives, etc.;
Ijoined the programme because I wanted to learn a skill I could earn from. I used to do some hairdressing before but that was not helping, many people are doing that.

- Maudlyn Russell, welder 
(c) approach these institutions with a specific proposal, asking them to help implement it;

(d) help the staff of the assisting agencies to understand the needs of the women involved and the importance of helping them as part of their own larger institutional goals;

(e) recognize that it will take time and patience to work out a means of collaborating, to remind the agencies of their agreements, and to resist getting discouraged.

5. Establishing a cooperative is not easy and specific expertise should be sought. There are programs in most countries, often private, that have some experience in this area and can provide advice.

6. The project should be kept small to begin with and should not be enlarged or duplicated until it has gained solid experience. The temptation always is to expand too quickly in order to serve more women. For example, the Bureau now believes that 20 participants would have been a more workable size for the Hanover Street project. Many of the project's problems might have been avoided if the group had been smaller

\section{I feel better in my community because everybody calls me a "welder." Sometimes people come to visit me who are unsure of my exact address and ask for the welder-girl.}

- Cynthia Anderson, welder

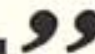

and thus more easily managed.

7. A new project of the size and complexity of Hanover Street requires a fulltime project manager of its own from the beginning and throughout development. The expense should be included in the initial planning. The group itself should interview and hire the manager so it is clear she/he is in the employ of the group. Careful monitoring and supervision by the manager, the implementing agency, and the group itself, should be part of ongoing program development in order to spot troubles early

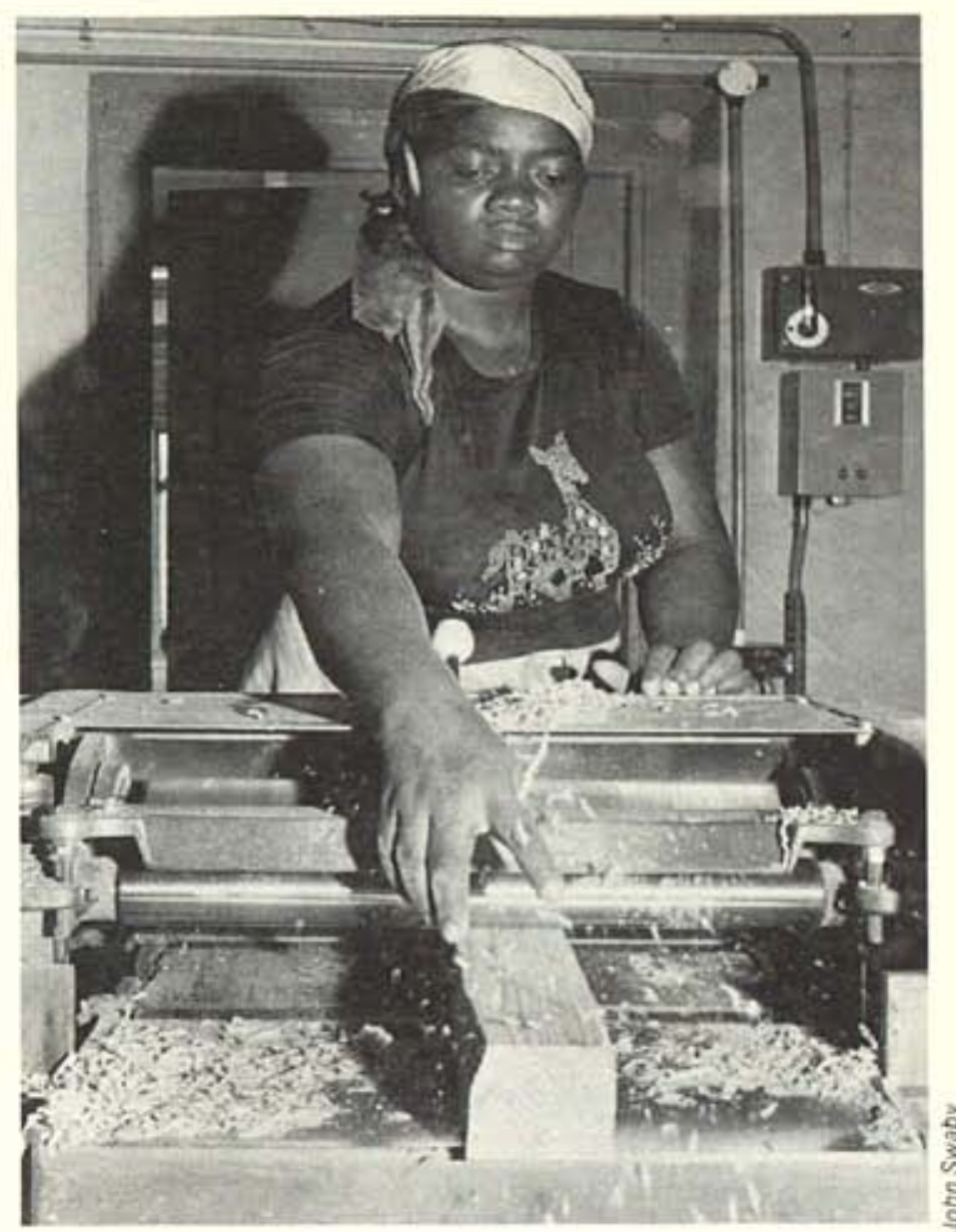

and deal with them before they become serious.

8. Agencies entering a community to help women should first talk with the women to find out about their skills and strengths, their perceptions of their problems, and possible solutions. A sense of shared experience among the women provides the basis for cooperative action.

9. It is preferable to work with a preexisting group or with neighbors. The cohesiveness, logistics, and security of the group will be strengthened by such bonds.

10. Perhaps the most important lesson to be learned from Hanover Street is the importance of learning from experience, and the recognition that problems and setbacks are part of that experience. Difficulties and failures need not be seen as negative or as a sign of weakness. Rather, they can become positive learning experiences. The important thing is to recognize them for what they are - learning experiences - and to build on them so that the same problems and mistakes are avoided in the future. 


\section{Appendix}

The following examples of projects offering training for women in non-traditional skill areas have been brought to our atten. tion.

Low-Income Women's Employment Project San Antonio, Texas

Lupe Anguiano, Project Director

A Department of Labor funded program for minority women to train them to become heavy equipment operators, welders, X-ray technicians, as well as for white-collar and health-related jobs. Rationale is that better paying jobs are in "nontraditional" fields and women must have access to these opportunities if they are to break out of the poverty cycle. The program attempts to address the needs of individual women through services such as job and training placement, pre-job orientation, counseling and referrals to support services such as day care.

For more information, write to:

Women's Bureau

Department of Labor

Washington, D.C. 20210 U.S.A.

\section{Graphic Arts International Union}

Washington, D.C.

The Graphic Arts International Union (AFL-ClO), has a program to train and upgrade approximately 140 women in nontraditional jobs in the printing industry.

For more information, write to:

Beryl Brown

Graphic Arts International Union

1900 "L" Street, N.W.

Washington, D.C. 20036 U.S.A.

or

Don Olsen

ETA Office of National Programs

U.S. Department of Labor

Washington, D.C. 20210 U.S.A.

\author{
African Training and Research Centre for \\ Women (ATRCW) \\ United Nations Economic Commission \\ for Africa \\ Addis Ababa, Ethiopia
}

ATRCW offers training opportunities in a number of non-traditional skill areas. They have introduced a program of handblock printing of textiles in Ethiopia and women have been trained in the male-dominated area of glass bead making in Ghana. Traditional pottery making skills are being upgraded to include production of indigenous construction materials such as brick, tile, and pipe. A program to train Tunisian women in electronics is now being developed in collaboration with ILO. During 1980-81, the center plans to implement training for women in such areas as welding, minor electric and electronic repairs, plumbing and construction skills. This will be done primarily by opening up pre-vocational training facilities currently providing training only to men, to women. Training in industrial skills linked to national development programs will be undertaken in several countries in the near future.

For more information, write to:

Nancy J. Hafkin

African Training \& Research Center for Women

Center for Women

U.N. Economic Commission for Africa

P.O. Box 3001

Addis Ababa, Ethiopia 
Design Three to Make Ready Graphics

Typography Alphabette

Cover Photo John Swaby

Printing Tartan Executive Services

We invite your comments and your ideas for projects which might be included in future editions of SEEDS. If you would like additional copies of this issue or would like to be included on the SEEDS mailing list, please write to:

Ann Leonard, Editor

SEEDS

P.O. Box 3923

Grand Central Station

New York, New York 10163 U.S.A. 


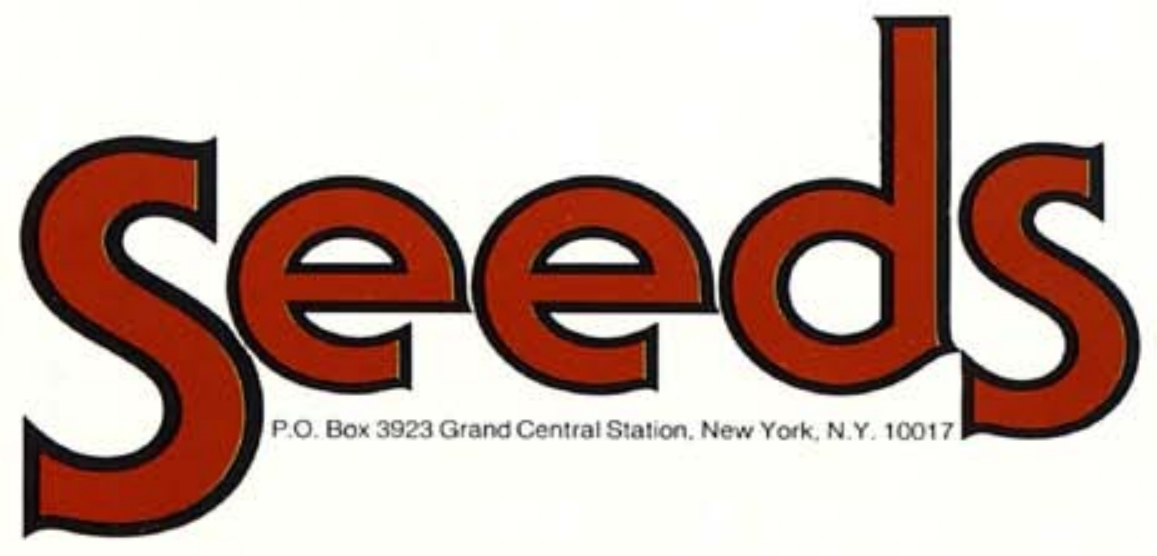

